\title{
Hrafn Sveinbjarnarson, fyrsti íslenski læknirinn. Minning 800 árum síðar
}

\author{
Ráðstefna á Hrafnseyri við Arnarfjörð, 24. ágúst 2013
}

\section{Sigurður Guðmundsson}

læknir, sérfræðingur í lyflækningum og smitsjúkdómum, lyflækningasviði Landspítala, prófessor, læknadeild

Háskóla Íslands.

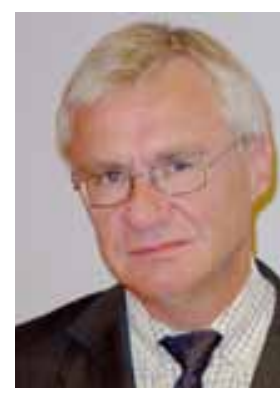

siggudm@landspitali.is

„Atburðir margir, peir er verða, falla mönnum oft úr minni en sumir eru annan veg sagðir en verið hafa og trúa pví margir er logið er en tortryggja pað satt er". ${ }^{1}$ Pannig hefst Hrafns saga Sveinbjarnarsonar hin sérstaka. Parna lýsir höfundur réttmætum efasemdum sínum um langminni lýðsins. Раð var hverfult á tímum söguritara rétt eins og nú. Ekki á pað síst við pegar fjallað er um pólitík, pá eins og nú.

Hrafns saga fjallar enda um pólítík. Hún er talin vera nokkurs konar pólitískt varnarrit að Hrafni látnum undir miklum áhrifum frá helgisögnum miðalda. ${ }^{2}$ Útdráttur Hrafns sögu sem birtist í Sturlungu er styttri, ekki síst hefur höfundur Sturlungu fellt úr peim köflum sem mest gera úr helgiljóma Hrafns, en meira fjallað um deilur hans við banamann sinn Porvald Vatnsfirðing. ${ }^{2}$ Sagan hin sérstaka minnir pví e.t.v. á ævisögur samtímans, einkum pær sem skrifaðar eru af aðdáendum nýlátinna mikilmenna.

Pví mikilmenni var Hrafn, fjölvís hæfileikamaður. Ef hann hefði fæðst nokkrum öldum síðar hefði hann vafalítið orðið okkar helsti endurreisnarmaður. Honum er svo lýst í sögunni að hafa orðið „snemmendis mikill atgervismaður. Hann var völundur að hagleik bæði að tré og að járni og skáld“, en höfundur sögunnar bætir par við af sagnfræðilegu raunsæi og heiðarleik að "pó hann hafi fátt kveðið svo að vér vitum". Pessi viðbót hlýtur að auka trúverðugleik og heilindi söguritara. Hrafni er svo áfram lýst að hann var „hinn mesti læknir og vel lærður, ... , lögspakur maður og vel máli farinn og að öllu fróður“. Honum er ennfremur lýst sem miklum á velli og atgervismanni, hann var „syndur vel og við allt fimur pað er hann hafðist að, bogmaður mikill og skaut manna best handskoti“.

Petta er maðurinn sem við íslensir læknar viljum að sé minnst sem fyrsta íslenska lærða læknisins, mannsins sem ætti að hafa læknanúmerið 0001. Auðvitað hafa ýmsir aðrir landar okkar sinnt sjúkum, læknað og líknað á pessum tímum, par með talið löngu fyrir hans daga. Heimildir munu pó óvissar um skólun peirra, pó snjallir væru peir margir. Erfitt er að minnast ekki á hvernig Porgerður Egilsdóttir læknaði föður sinn Skallagrímsson af hugsýki og sorg í sjálfsvígshugleiðingum eftir sonarmissi. Hún beitti par brögðum og mannlegu innsæi, aðferðafræði sem enn er beitt í nútíma læknisfræði. Kannski var porgerður fyrsti íslenski geðlæknirinn eða geðhjúkrunarfræðingurinn.

Í Hrafni höfum við læknar samt ákveðið tákn, hann var okkar fyrstur, og pannig viljum við hugsa til hans. Hann er okkur nauðsynlegur sem upphaf, einhvers konar ármaður. Síðan hefur okkur fjölgað, að vísu hægt næstu aldirnar en hraðar síðar, og pekking okkar vaxið og dafnað. Næsti bautasteinn læknisfræðinnar hérlendis er svo auðvitað Bjarni Pálsson, um fimm og hálfri öld síðar, sem líka á að vera okkur tákn og fyrirmynd. Peir Hrafn og Bjarni verðskulda háan sess í hugum okkar nútímalækna, og ég held að pann sess hafi peir báðir.
Um Hrafn, ævi hans sem höfðingja, pílagríms og læknis verður fjallað á ráðstefnu sem haldin verður á Hrafnseyri pann 24. ágúst n.k. Hún er haldin til að minnast pess að 800 ár voru í mars síðastliðnum liðin frá pví að Porvaldur Vatnsfirðingur stóð að vígi Hrafns. Á ráđstefnunni munu fimm fræðimenn fjalla um ævi hans, lækningar, kirkjuleg áhrif, skáldskapinn og pólitískar deilur. Fleiri munu einnig um hann fjalla í tali og tónum. Ágrip erinda eru birt í pessu tölublaði Læknablaðsins ásamt fjölbreyttri dagskrá. Hrafni og ævi hans hafa áður verið gerð góð skil á síðum blaðsins af peim Erni Bjarnasyni ${ }^{3,4}$ og Páli Ásmundssyni. ${ }^{5}$ Hér leggja fleiri hönd á plóg, fólk með pekkingu á sagnfræði, trúarbrögðum, norrænum fræðum og lækningum tekur höndum saman og bregður skýrara ljósi á ævi og störf pessa merka manns, táknmyndar okkar lækna.

\section{Heimildir}

1. Hrafns saga Sveinbjarnarsonar hin sérstaka. Sturlunga saga II. Ritstj. Örnólfur Thorsson, Svart á hvítu 1988: 883931.

2. Sturlunga saga, skýringar og fræði. Inngangur. Ritstj. Örnólfur Thorssson, Svart á hvítu 1988:xxviii

3. Örn Bjarnason. Kristinn heimur miðalda og Hrafn Sveinbjarnarson. Læknablaðið 2004; 90: 167-70.

4. Örn Bjarnason. Hrafn Sveinbjarnarson - líkn og lækningar. Læknablaðið 2004; 90: 253-7.

5. Páll Ásmundsson. 800 ár frá vígi Hrafns Sveinbjarnarsonar. Læknablaðið 2013;99:164-5.

The first Icelandic physician, Hrafn Sveinbjarnarson. In memoriam $\mathbf{-} 800$ years later.

Sigurður Guðrmundsson Consultant in Internal Medicine and Infectious Diseses, andspitali University Hospital, Professor, School of Medicine, University of Iceland. 